\title{
C-Reactive Protein with Procalcitonin as a Marker of Occult Bacterial Infection in Fever Without a Focus
}

\section{Pooja M Hiremath, Narayanappa D and Rajani HS}

Department of Paediatrics, JSS Medical College, JSS Academy of Higher Education and Research, Mysore, India

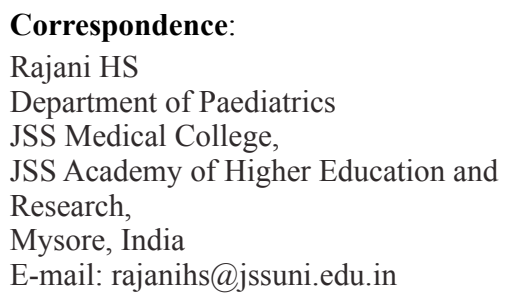

Department of Paediatrics

JSS Medical College,

JSS Academy of Higher Education and Research,

Mysore, India

E-mail: rajanihs@jssuni.edu.in

DOI: $10.3126 /$ jnps.v41i2.31167

Submitted on: $2020-09-12$

Accepted on: 2021-06-27

Acknowledgements: None

Funding: Nil

Conflict of Interest: None declared

Permission from IRB: Yes

To cite this article: Hiremath PM, Narayanappa D, Rajani HS. C- Reactive Protein With Procalcitonin as a Marker of Occult Bacterial Infection in Fever Without A Focus. J Nepal Paediatr Soc. 2021;41(2):134-9.

\begin{abstract}
Introduction: Fever without a focus constitutes a major problem in children in the age group of three months to 36 months. Majority have viral infections but around 1.6 - 2\% can have occult serious bacterial infection which needs early identification and treatment. The study was done to evaluate combination of CRP with Procalcitonin (PCT) as a marker of SBI in children (Three months to 36 months) with fever without focus in comparison with only PCT or CRP done separately.
\end{abstract}

Methods: In this hospital based explorative study, 31 children between three months to 36 months of age with fever without any localising signs were enrolled. Relevant investigations were done to diagnose or rule out serious bacterial infection. Cut off of $>10$ $\mathrm{mg} / \mathrm{dl}$ for CRP and $>0.5 \mathrm{ng} / \mathrm{ml}$ for PCT was considered. Appropriate statistical analysis was done.

Results: Among 31 recruited cases, 14 had occult serious bacterial infection with urinary tract infection being the most common cause. The combination PCT with CRP had sensitivity of $78.5 \%$, specificity of $100 \%$, and positive predictive value of $100 \%$ and negative predictive value of $85 \%$. Diagnostic accuracy was $90.32 \%$ which did not have any statistically significant difference compared to PCT alone but significant compared to CRP alone.

Conclusions: Combining CRP with procalcitonin did not have any added advantage over procalcitonin alone but combination of CRP and PCT and PCT alone is useful in detecting occult serious bacterial infections in children with fever without focus compared to CRP alone.

Keywords: Children; CRP; Procalcitonin; Serious bacterial infection 


\section{INTRODUCTION}

Fever without localising signs constitutes a major problem in children in the age group between three months to 36 months. Majority of these children have viral infections. Studies done previously ${ }^{1-3}$ have shown that about $1.6-3.0 \%$ of these children have occult bacterial infections which may progress to serious bacterial infections (urinary tract infections, meningitis, pneumonia, etc.) in $5-10 \%$. Clinical data alone may be unreliable in distinguishing between patients with occult bacteraemia from those without occult bacterial infections. Thus, it is important to identify the children with occult bacterial infections early and treat them with the antibiotics there by preventing further complications and development of serious bacterial infections.

An effective and accurate biochemical marker is needed to diagnose occult bacterial infection. Paucity of specific markers of occult serious bacterial infection result in delaying treatment with antibiotics or over treating those without occult bacterial infections with antibiotics. Unnecessary use of antibiotics may lead to antibiotic resistance. Thus, specific biomarker is needed with increased sensitivity, specificity and diagnostic accuracy to differentiate between those who are having occult bacterial infections from those not having occult bacterial infection.

C Reactive Protein (CRP) and Procalcitonin (PCT) have been identified as the markers for diagnosing bacterial infections. In this study attempt is made to evaluate combination of CRP with PCT as a marker of occult bacterial infection, in children (Three months - 36 months) with fever without focus in comparison with CRP and PCT alone.

\section{METHODS}

This was a hospital based explorative study conducted in a tertiary care hospital over a period of one and half years. Sample size was calculated, using the prevalence rate of occult bacterial infections in fever without focus as $2 \%$ based on previous studies. ${ }^{1-3}$ Any child between the age group of three months to 36 months, presenting with fever (Axillary temperature $>39^{\circ} \mathrm{C}$ ) without any localising signs and had undergone immunisation with conjugate vaccines

(Pneumococcal and $\mathrm{H}$ influenza vaccines) were included in the study. Children who have received prior antibiotics, children with fever attributable to vaccination, children who are immunocompromised (chronic liver and kidney disease etc.) and children with fever without focus with toxic look were excluded. Toxic features included lethargy, signs of poor perfusion, marked hypoventilation, hyperventilation or cyanosis. Lethargy was defined as level of consciousness characterised by poor or absent eye contact or as failure of child to recognise the parents or to interact with persons or objects in the environment.

An informed written consent was obtained from parents. A detailed history, including immunisation status was recorded along with complete clinical examination in a proforma. Provisional diagnosis was made by the treating paediatrician subsequently confirmed or revised after investigations. All children recruited were subjected to the following investigations: CBC, PCT, CRP, blood culture, urine RE/ME, urine culture, chest $\mathrm{X}$ ray, lumbar puncture with CSF analysis, dengue serology was performed as and when the clinical situation mandated it. Occult bacterial infection was defined as bacteraemia, meningitis, pneumonia, or urinary tract infection in which focal signs were not evident on clinical examination.

CRP analysis was done using quantitative test latex enhanced immunoturbidimetry using ready to use reagents. The test has the sensitivity with lower of $1 \mathrm{mg} / \mathrm{dl}$. Using this method cut off is taken 10 $\mathrm{mg} / \mathrm{dl}$. PCT was measured using Elecsys BRAHMS - PCT kit which was based on sandwich principle, duration of assay was $18 \mathrm{~min}$. Measuring range $0.02-100 \mathrm{ng} / \mathrm{ml}$ with cut off value of $0.5 \mathrm{ng} / \mathrm{ml}$. The statistical analysis was done using statistical software SPSS (version 21.0). The results of Procalcitonin, CRP and CRP with Procalcitonin were analysed using Pearson's chi square method in term of sensitivity, specificity, positive predictive value, negative predictive value, positive and negative likelihood ratios. The diagnostic accuracy of all the parameters was then compared and interpreted with reference to clinical data. 
A comparison of diagnostic accuracy of these markers was made by AUROCC by calculating area under the curve. Difference in the accuracy was determined by comparing confidence intervals of their accuracies. If the confidence intervals did not overlap, then the difference was considered to be significant. The estimation analysis with confidence intervals was used to compare the accuracy. Institutional Ethical Committee approval was taken

\section{RESULTS}

Among the total 31 cases, 16 were between three months to 12 months of age and 15 were between 13 months and 36 months of age. Nineteen were males and 12 females. Following the investigation results, they were divided into two groups, one with occult bacterial infection and the other without occult bacterial infection. Children with occult bacterial infection received treatment as per standard hospital protocol.

Total 14 had serious bacterial infection (SBI) (Table I) with 13 children having UTI and one had pyogenic meningitis. Among 17 cases of non SBI, two were positive for dengue fever, one had rickettsial infection (scrub typhus) and in 14, etiology could not be identified and were discharged with a diagnosis of viral fever.

Among 14 cases with bacterial infection, 11 (78.5\%) cases had both CRP (>10 mg/dL) and PCT $(>0.5 \mathrm{ng} / \mathrm{ml})$ elevated and in the remaining three $(21.4 \%)$ cases both CRP $(<10 \mathrm{mg} / \mathrm{dL})$ and PCT $(<0.5 \mathrm{ng} / \mathrm{ml})$ were not elevated. Among 17 cases without occult bacterial infection, none had raised CRP $(>10 \mathrm{mg} / \mathrm{dL})$ nor raised PCT $(>0.5 \mathrm{ng} /$
Table 1. Proportion Of Occult Bacterial Infection in the Study Population

\begin{tabular}{|llcr|}
\hline & & Number & $\%$ \\
\hline $\begin{array}{l}\text { Fever } \\
\text { without } \\
\text { focus }\end{array}$ & $\begin{array}{l}\text { Without Occult } \\
\text { Bacterial }\end{array}$ & 17 & $54.8 \%$ \\
& $\begin{array}{l}\text { Infection } \\
\text { With Occult }\end{array}$ & 14 & $45.2 \%$ \\
& $\begin{array}{l}\text { Bacterial } \\
\text { Infection }\end{array}$ & & \\
& Total & 31 & $100.0 \%$
\end{tabular}

*Bacterial infection proven by the growth of pathogen in blood/ urine / other body fluids and diseases known to have been caused by bacteria most commonly

ml) with all 17 cases $(100 \%)$ having CRP $<10 \mathrm{mg} /$ $\mathrm{dL}$ and $\mathrm{PCT}<0.5 \mathrm{ng} / \mathrm{ml}$.

The sensitivity and specificity of PCT alone was $92.8 \%$ and $88.2 \%$ within $95 \%$ confidence interval respectively. The positive predictive value was $86.67 \%$ and the negative predictive value was $93.7 \%$. The diagnostic accuracy of CRP in detecting bacterial infection was $90.3 \%$. The sensitivity of CRP in detecting bacterial infection was $78.5 \%$ with the cut off limit is $10 \mathrm{mg} / \mathrm{dl}$ and specificity was $64.7 \%$. Positive predictive value was $64.7 \%$ and the negative predictive value was $78.5 \%$. The diagnostic accuracy of CRP in detecting bacterial infection was $70.9 \%$.

The combination of PCT with CRP had sensitivity of $78.5 \%$ (95\% CI, $52.4-92.43 \%)$ and specificity of $100 \%$ (95\% CI, $81.5-100 \%)$, positive predictive value of $100 \%$ (95\% CI, $74.1-100 \%$ ) and negative predictive value of $85 \%$ (95\% CI, $63.9-94.7 \%)$. There was no statistically significant difference between these values when compared to procalcitonin alone. Diagnostic accuracy was

Table 2. Comparison between Procalcitonin, CRP and CRP with Procalcitonin

\begin{tabular}{|lrrrrr|}
\multicolumn{1}{c}{$\begin{array}{c}\text { Sensitivity\% } \\
\text { At 95\% CI }\end{array}$} & \multicolumn{1}{c}{$\begin{array}{c}\text { Specificity\% } \\
\text { At 95\% CI }\end{array}$} & \multicolumn{1}{c}{$\begin{array}{c}\text { PPV\% } \\
\text { At 95\% CI }\end{array}$} & $\begin{array}{c}\text { NPV\% } \\
\text { At 95\% CI }\end{array}$ & $\begin{array}{r}\text { Diagnostic accuracy\% } \\
\text { At 95\% CI }\end{array}$ \\
\hline PCT & $\begin{array}{r}92.8 \% \\
(68.5,98.7)\end{array}$ & $(65.6,96.7)$ & $(62.1,96.2)$ & $(71.6,98.8)$ & $90.3 \%$ \\
CRP+ & $78.5 \%$ & $64.7 \%$ & $64.7 \%$ & $78.5 \%$ & $70.9 \%$ \\
& $(52.4,92.4)$ & $(41.3,82.6)$ & $(41.3,82.6)$ & $(52.4,92.4)$ & $(53.4,83.9)$ \\
CRP & $78.57 \%$ & $100 \%$ & $100 \%$ & $85 \%$ & $90.3 \%$ \\
PCT & $(52.4,92.4)$ & $(81.5,100)$ & $(74.1,100)$ & $(63.9,94.7)$ & $(75.1,96.6)$ \\
\hline
\end{tabular}




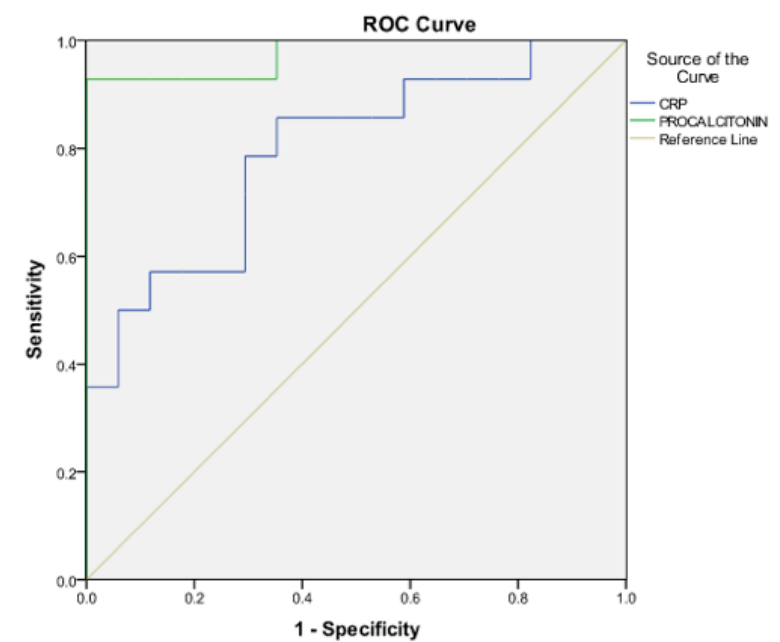

\begin{tabular}{|l|c|c|c|c|}
\hline \multicolumn{4}{|c|}{ Area Under the Curve } \\
\hline $\begin{array}{l}\text { Test Result } \\
\text { Variable(s) }\end{array}$ & Area & P & \multicolumn{3}{|c|}{$\begin{array}{c}\text { Asymptotic } 95 \% \\
\text { Confidence Interval }\end{array}$} \\
\hline CRP & & & $\begin{array}{l}\text { Lower } \\
\text { Bound }\end{array}$ & $\begin{array}{c}\text { Upper } \\
\text { Bound }\end{array}$ \\
\hline Procalcitonin & 0.975 & 0.000 & 0.922 & 1.000 \\
\hline
\end{tabular}

Figure 1. ROC curve for PCT and CRP with respect to sensitivity and specificity

$90.3 \%(95 \%$ CI, $75.1,96.65)$ which is similar to that of PCT. (TABLE 2)

PCT has the greater AUC (0.975) as compared to CRP (0.506). From the ROC curve, with cut off of PCT at $2.9 \mathrm{ng} / \mathrm{ml}$, sensitivity was $92.86 \%$ and specificity was $100 \%$ and with cut off for CRP at 9 $\mathrm{mg} / \mathrm{dl}$, sensitivity was $85.7 \%$ and specificity was 64.7\%. Combination of both CRP and PCT had sensitivity of $85.7 \%$ and specificity of $100 \%$. (Figure 1). Addition of CRP with PCT had no added advantage over procalcitonin alone in detecting occult bacterial infection but CRP alone was inferior compared to combination of PCT and CRP in detecting occult bacterial infection.

\section{DISCUSSION}

Fever without localising signs in children in the age group of three months to 36 months is common presenting complaint encountered by the paediatrician. Most have viral infections but a minor proportion of these children have occult bacterial infection. Thus, it becomes important to identify these children and treat them with the antibiotics at the earliest to prevent further complications, and to prevent growth resistant organisms and unnecessary financial burden. Hence in order to find those children with occult bacterial infection a best biomarker is needed with higher sensitivity, specificity and diagnostic accuracy.

In our study sample, when investigations were done, $45 \%$ had SBI in the form of UTI. We had only one case of pyogenic meningitis diagnosed by CSF analysis but no microorganism was isolated. UTI is the most common SBI in this age group in concordance with other studies. ${ }^{4}$ There were no infections related to organisms covered by vaccination. SBI prevalence in previous studies was shown to range between $11 \%$ and $29 \% .^{4}$ The prevalence of SBI is more in our study as only children hospitalised were included in the study.

Various studies have been conducted evaluating PCT and CRP alone as a marker of occult bacterial infection. We found that PCT has good predictive value for detecting bacterial infection. As per the Pearson chi square test, this is statistically significant with $\mathrm{P}<0.0001$. The results obtained were similar to the results concluded by Simon et $\mathrm{al}^{5}$ and the meta-analysis by Yo et $\mathrm{al}^{6}$ which showed a similar significance of $\mathrm{P}<0.05$. This meta analysis included 11 studies that studied the diagnostic value of either PCT alone or in comparison with other markers, like CRP or leukocyte count. Overall sensitivity and specificity of PCT was $0.83(95 \%$ CI 0.70 to 0.91$)$ and 0.69 (95\% CI 0.59 to 0.85$)$, for CRP, it was $0.74(95 \%$ CI 0.65 to 0.82 ) and 0.76 (95\% CI 0.70 to 0.81 ), and 0.58 (95\% CI 0.49 to 0.67$)$ and 0.73 (95\% CI 0.67 to 0.77 ) for leukocyte count respectively. The conclusion was PCT is a better marker than leukocyte count and CRP for detecting SBI among children with fever without source. ${ }^{6}$

The sensitivity of PCT in detecting bacterial infections at a cut off of $>0.5 \mathrm{ng} / \mathrm{ml}$ comes to $92.86 \%$ and the specificity is $88.24 \%$, similar to Andreola et al. ${ }^{7}$ In their prospective, observational study among 408 children, it was concluded that both PCT and CRP were valuable markers in predicting SBI in children with fever without 
source, performing better than WBC and ANC. In our study, with sensitivity (92.86\%) and specificity (88.24\%), the positive predictive value of PCT is $86.67 \%$ and negative predictive value is $93.75 \%$. The positive likelihood ratio of PCT in predicting bacterial illness is $7.893(2.928-21.28)$ and negative likelihood ratio is $0.080(0.0112-$ 0.5848). Our findings are similar to the results of Andreola et al. ${ }^{6}$ Lacour et al. revealed a positive likelihood ratio of 4.92 (95\% CI $3.26-7.43)$ and negative likelihood ratio of $0.07(0.02-0.27)$. PCT had the best sensitivity (93\%) and negative predictive value (96\%). This study concluded PCT and CRP were better than IL-6, WBC, and/or band count in predicting SBI. ${ }^{8}$ Another study by Thayyil et $\mathrm{al}^{9}$ in 2005 reported the highest positive likelihood ratio of 10.67 (95\% CI 2.9 - 39.3). They had used thresholds for all the three blood tests i.e. PCT $>2 \mathrm{ng} / \mathrm{ml}, \mathrm{CRP}>50 \mathrm{mg} / \mathrm{l}$, and WBC count of $>15 \times 10^{9} / 1$. The major drawback of this study was the negative likelihood ratio of $0.52(0.25-1.05)$ which lacked 'rule out' value. That is this triad of cut off values could accurately 'rule in' but not 'rule out' bacterial infections.

Two studies have looked at the predictive value of HsCRP and PCT in febrile children less than 16 years of age, similar to our study. The largest one was by Gendrel et al. ${ }^{10}$ wherein PCT values were ascertained for 700 children and in about 360 patients an infectious etiology was obtained. Children were assigned to three groups based on the final diagnosis - invasive bacterial infections ( $\mathrm{n}$ $=46)$, localised bacterial infections $(n=78)$ and viral infections $(n=236)$. The mean PCT level of the first group was $45.9 \mathrm{ng} / \mathrm{ml}$, the second was 4.2 $\mathrm{ng} / \mathrm{ml}$ and the third was $0.4 \mathrm{ng} / \mathrm{ml}$. PCT was found to be the most useful test, the next best being CRP. PCT has a diagnostic accuracy of $90.3 \%$, in our study, in predicting bacterial infections in febrile children. Hence PCT is the best marker in reasonably excluding bacterial infection if the values are $<0.5 \mathrm{ng} / \mathrm{ml}$. Also, PCT has a higher negative predictive value $(93.75 \%)$ than positive predictive value $(86.67 \%)$. Hence it can be used for excluding or 'rule out' SBI in children.

Further, on comparing the characteristics of culture proven bacterial infection with PCT values, the following could be inferred. Of the total of 13 cases with urine culture positive and one case with blood culture positive, all 14 cases $(61.3 \%)$ had PCT values $>0.5 \mathrm{ng} / \mathrm{ml}$. Among cases with sterile blood culture, $17(54.8 \%)$ had PCT values $<0.5 \mathrm{ng} / \mathrm{ml}$. This supports our observation that PCT can be safely used in the exclusion of septicaemia. The association is statistically significant with $p<0.05$ as per Pearson chi square test.

Among the loco-regional infections studied, it was found that PCT had a significant predictive value in diagnosing UTI. Literature search shows that the rise of PCT can be used in predicting upper urinary tract involvement. In a study by Leroy et $\mathrm{a}^{11} \mathrm{PCT}$ was found to demonstrate a reasonable diagnostic accuracy for both acute pyelonephritis and renal scarring and was a more accurate predictor than either CRP or WBC count. $100 \%$ cases with negative urine culture had PCT values $<0.5 \mathrm{ng} / \mathrm{ml}$, where as $80 \%$ cases with UTI had PCT values $>0.5$ $\mathrm{ng} / \mathrm{ml}$. The rise of PCT correlates well with UTI with or without upper urinary tract involvement. Our study contained only cases with lower urinary tract involvement. Hence, it can be concluded that UTI can be almost excluded if PCT $<0.5 \mathrm{ng} / \mathrm{ml}$. The Pearson chi square correlation test for PCT in diagnosing UTI is highly significant with $\mathrm{P}<$ 0.0001 .

Putto et al ${ }^{12}$ studied CRP and WBC counts in 151 children and reported that CRP had a far superior sensitivity $(100 \%)$ and specificity $(75 \%)$ for the detection of bacterial infection compared to WBC counts. In a prospective observational study by Olaciregui et al., ${ }^{13}$ they had obtained a sensitivity of $63.4 \%$ and a specificity of $84.2 \%$, using a higher cut off level of CRP of $30 \mathrm{mg} / \mathrm{dl}$ with a prevalence of SBI of $23.63 \%$. Yo et $\mathrm{al}^{6}$ found the mean AUC for CRP to be 0.84 , which is correlating with our study in which the AUC for CRP is 0.72 .

The positive predictive value of CRP in our study is $27.7 \%$ which is less than that for PCT. The negative predictive value of CRP is high $90.6 \%$ and is comparable to that of PCT i.e. $89 \%$. Thus, it can be concluded that CRP is inferior to PCT in diagnosing or 'ruling in' bacterial infection. The positive likelihood ratio of CRP is 2.226 (1.53 3.24 ) and the negative likelihood ratio is 0.3312 
(0.156 - 0.7015) which are inferior to those obtained with PCT.

Our study has significant findings but it is also limited by the fact that it has been conducted among a very small sample size in a single centre. Our findings need to be corroborated further with larger, multi centric studies in the future.

\section{CONCLUSIONS}

In this study, addition of CRP with PCT had no added advantage over PCT alone in detecting occult SBI but CRP alone was inferior compared to combination of PCT and CRP in detecting SBI. Hence, in a poor resource setting, PCT alone can be considered to detect SBI in children between three to 36 months of age, with fever without focus.

\section{REFERENCES}

1. Lee GM, Harper MB. Risk of bacteremia for febrile young children in the post-Haemophilus influenzae type b era. Arch Pediatr Adolesc Med. 1998 Jul;152(7):624-8. DOI: 10.1001/archpedi.152.7.624.

2. Sur DK, Bukont EL. Evaluating fever of unidentifiable source in young children. Am Fam Physician. 2007 Jun 15;75(12):1805-11. PMID: 17619522

3. Alpern ER, Alessandrini EA, Bell LM, Shaw KN, McGowan KL. Occult bacteremia from a pediatric emergency department: current prevalence, time to detection, and outcome. Pediatrics. 2000 Sep;106(3):505-11. DOI: 10.1542/ peds.106.3.505. PMID: 10969095.

4. Moldovan DA, Baghiu MD, Balas A, Truta ST. The Value of the "Lab-Score" Method in Identifying Febrile Infants at Risk for Serious Bacterial Infections. J Crit Care Med (TarguMures). 2015;1(1):11-17. DOI:10.1515/ jccm-2015-0003

5. Simon L, Gauvin F, Amre DK, Saint-Louis P, Lacroix J. Serum procalcitonin and C-reactive protein levels as markers of bacterial infection: a systematic review and meta-analysis. Clin Infect Dis. 2004 Jul 15;39(2):206-17. DOI: 10.1086/421997. Erratum in: Clin Infect Dis. 2005 May 1;40(9):1386-8. PMID: 15307030.

6. Yo CH, Hsieh PS, Lee SH, Wu JY, Chang SS, Tasi KC, et al. Comparison of the test characteristics of procalcitonin to $\mathrm{C}$-reactive protein and leukocytosis for the detection of serious bacterial infections in children presenting with fever without source: a systematic review and meta-analysis. Ann Emerg Med. 2012 Nov;60(5):591-600. DOI: 10.1016/j.annemergmed.2012.05.027.

7. Andreola B, Bressan S, Callegaro S, Liverani A, Plebani M, Da Dalt L. Procalcitonin and C-reactive protein as diagnostic markers of severe bacterial infections in febrile infants and children in the emergency department. Pediatr Infect Dis J. 2007 Aug;26(8):672-7. DOI: 10.1097/INF.0b013e31806215e3.

8. Lacour, Zamora S, Gervaix A. Bedside Procalcitonin and C Reactive Protein Tests in Children with Fever Without Localizing Signs of Infection Seen in a Referral Center. Pediatrics. 2003;112(5):1054-60. DOI: 10.1542/peds. 112.5 .1054

9. Thayyil S, Shenoy M, Hamaluba M, Gupta A, Frater J, Verber IG. Is procalcitonin useful in early diagnosis of serious bacterial infections in children? Acta Paediatr. 2005;94(2):155-8. DOI: 10.1111/j. 1651-2227.2005.tb01883.x. PMID: 15981747.

10. Gendrel D, Raymond J, Coste J, Moulin F, Lorrot M, Guérin S, et al. Comparison of procalcitonin with C-reactive protein, interleukin 6 and interferon-alpha for differentiation of bacterial vs. viral infections. Pediatr Infect Dis J. 1999 Oct;18(10):875-81. DOI: 10.1097/00006454-199910000-00008.

11. Leroy S, Gervaix A. Procalcitonin: a key marker in children with urinary tract infection. Adv Urol. 2011;2011:397618. DOI:10.1155/2011/397618.

12. Putto A, Ruuskanen O, Meurman O, Ekblad H, Korvenranta H, Mertsola J, et al . C reactive protein in the evaluation of febrile illness. Arch Dis Child. 1986 Jan;61(1):24-9. DOI: 10.1136/adc.61.1.24.

13. Olaciregui I, Hernández U, Muñoz JA, Emparanza JI, Landa JJ. Markers that predict serious bacterial infection in infants under 3 months of age presenting with fever of unknown origin. Arch Dis Child. 2009 Jul;94(7):501-5. DOI: $10.1136 /$ adc.2008.146530. 